\title{
Ceramic Coatings for High-Temperature Protection of Steel
}

\author{
By William N. Harrison, Dwight G. Moore, and Joseph C. Richmond
}

\begin{abstract}
A new type of ceramic coating for the protection of low-carbon steel in high-temperature service was developed during the war at the National Bureau of Standards and was used by the Army and Navy on the exhaust systems of certain aircraft and other vehicles. The outstanding features of these coatings are (a) high resistance to chipping under repeated thermal shock, (b) protection of the metal against oxidation during prolonged exposure at temperatures up to about $1,250^{\circ} \mathrm{F}$, (c) freedom from the cracking and blistering produced in conventional porcelain enamels under comparable conditions of high temperature and severe thermal gradients, and (d) a mat surface which does not show high lights and, therefore, decreases the visibility.
\end{abstract}

\section{Introduction}

Early in the war, crucial shortages of a number of materials essential to its prosecution appeared imminent. The outlook regarding nickel and chromium was particularly dark owing to the greatly increased demand that was anticipated for these metals as constituents of alloys, and also because normal importation of these ores was endangered.

In an effort to alleviate this situation, a project was undertaken at the National Bureau of Standards with a view to the possible replacement of nickel-chromium alloys by ceramic-coated steel in a number of high-temperature applications. The exhaust manifolds of certain automobile engines had for some years been coated with the conventional type of glossy porcelain enamel, and the use of this type of glossy coating was proposed by a number of organizations in the industry. The work at the Bureau included the testing of such coatings submitted by manufacturers, but, in addition, it involved the development of a new type of ceramic coating having properties peculiarly suited to high-temperature use.

When the development work was begun in 1942 , it was recognized that there were several properties which were of especial importance in a coating for the intended purpose. These include the following: 1. It should adhere well to the metal; 2. The coating should be thin, both to reduce weight and to minimize the likelihood of cracking and chipping due to accidental mishandling; 3 . There should be no "reboil"; ${ }^{1} 4$. It should protect the steel against oxidation when used at high temperatures for prolonged periods; 5. It should have high resistance to thermal shock and to temperature gradients.

Such a new type of coating was developed and was described to the armed services in June 1943 in a report also containing comparative data on conventional type porcelain enamel coatings. The present paper comprises most of the information in that initial report, as well as supplementary material on service tests, compositions, and technic of application as used in regular production of exhaust parts for the armed services.

\section{Development of High-Temperature Ceramic Coatings}

\section{Study of Refractory Admixtures}

After a consideration of the previously outlined properties that were desirable in a high-temperature protective coating, it was concluded that a coating of greater refractoriness than that of con-

\footnotetext{
1 "Reboil" may be defined as the appearance in the coating of gas bubbles usually occurring at or near $1,100^{\circ} \mathrm{F}$ when porcelain-enameled iron or steel is reheated after the first firing operation.
} 
ventional ground coats would be required. In order to achieve this property, it was believed most promising to add refractory mill additions ${ }^{2}$ to the conventional-type enamel ground-coat frit ${ }^{3}$ rather than to make the frit itself highly refractory, which would involve its being difficult to handle in the smelting furnace. It was also believed desirable to depart from the conventional glossy enamel finish and to develop a mat surface that, in conformity with military practice, would have low visibility because of its freedom from high lights.

To accomplish these purposes, various refractory materials, singly and in combination, were added as mill additions in varying amounts to conventional ground coat enamel frits. Batch compositions of the two base frits used, ${ }^{4}$ together with the computed chemical compositions, are given in table 1 . The admixtures that were tried included zirconium oxide, titanium dioxide, ferric oxide,

TABLE 1.-Batch weights and computed chemical compositions of ground coat porcelain enamel frits 1 and 11

BATCH WEIGHTS

\begin{tabular}{|c|c|c|}
\hline \multirow{2}{*}{ Ingredient } & \multicolumn{2}{|c|}{ Parts by weight } \\
\hline & Frit 1 & Frit 11 \\
\hline Feldspar ... & 31.0 & 31.0 \\
\hline Flint & 11. 4 & 18.0 \\
\hline Borax .......... & 37.1 & 37.1 \\
\hline Soda ash _. . . . . & 5.9 & 5.9 \\
\hline Soda nitre & 3.8 & 3.8 \\
\hline Fluorspar. .......... & 9.0 & 3. 0 \\
\hline Cobalt oxide & 0.5 & 0.5 \\
\hline Nickel oxide & .4 & .6 \\
\hline \multirow[t]{2}{*}{ Manganese oxide } & .9 & 1. 1 \\
\hline & 100.0 & 101.0 \\
\hline
\end{tabular}

COMPUTED CHEMICAL COMPOSITION

\begin{tabular}{l|r|r}
\hline $\mathrm{SiO}_{2}$ & & \\
$\mathrm{Al}_{2} \mathrm{O}_{3}$ & 40.9 & 49.2 \\
$\mathrm{~B}_{2} \mathrm{O}_{3}$ & 7.7 & 7.7 \\
$\mathrm{CaO}$ & 17.5 & 17.4 \\
$\mathrm{~K}_{2} \mathrm{O}$ & 8.4 & 2.9 \\
$\mathrm{Na}_{2} \mathrm{O}$ & 4.5 & 4.5 \\
$\mathrm{~F}_{2}$ & 15.3 & 15.2 \\
$\mathrm{NiO}$ & 3.5 & .04 \\
$\mathrm{CoO}$ & 0.5 & .7 \\
$\mathrm{MnO}_{2}$ & .6 & .6 \\
& 1.2 & 1.4 \\
\hline
\end{tabular}

$2 \mathrm{~A}$ mill addition is any material placed in the ball mill prior to the grinding of the coating for application to the metal.

3 Frit is a term used in the enamel industry to refer to the material resulting from the quenching and shattering of the molten glass as it is poured into cold water from the smelting furnace. aluminum oxide, chromic oxide, silicon dioxide, silicon carbide, feldspar, mullite, and chrome ore.

The coatings, as prepared from the two frits with the various refractory admixtures, were applied to low carbon steel specimens and fired at temperatures up to $1,650^{\circ} \mathrm{F}$. They were then examined for surface texture and adherence. The ones showing promise were heated for periods of several hours at a temperature of $1,650^{\circ} \mathrm{F}$ in order to obtain rapidly an indication of their effectiveness. In these early heating tests, chipping, "burn-off," flow of the coating, and blistering were common defects. Of the various coatings included, those containing alumina showed the best possibilities.

It was noted early in the work that alumina had a very powerful effect in raising the viscosity of the coatings. During firing, the $A-19$ coating (table 3) was not "tacky" like an ordinary ground coat, and accidental touching of the coating with firing tools at $1,600^{\circ} \mathrm{F}$ did not cause sticking. At a temperature of $1,200^{\circ} \mathrm{F}$, specimens protected with coatings high in alumina would not adhere to each other, even when placed in intimate contact. To obtain more specific comparisons, frit 11 was dry-ground in a pebble mill to a fineness such that about 1 percent was retained on a No. 200 sieve. At the same time, a number of oxide admixtures were ground to approximately the same fineness.

Mixtures were prepared from the resulting fine powders in the ratio 80 percent by weight of frit to 20 percent of oxide. A solution of gum arabic was added in sufficient quantity to give coherence, after which cylinders $5 / 8 \mathrm{in}$. in diameter were dry-pressed at $10,000 \mathrm{lb} / \mathrm{in}^{2}$. After the cylinders had dried they were reduced to a uniform length of $3 / 4 \mathrm{in}$.

Before firing each cylinder it was placed on a small plaque of stainless steel that had been sprinkled with a thin layer of finely divided calcined alumina. The cylinders were then inserted in a vertical position into a furnace at $1,600^{\circ} \mathrm{F}$ for 10 minutes, after which they were removed and cooled slowly to room temperature.

Figure 1 shows the results of these tests. Frit 11 with no addition fused to a button, whereas the same frit with the 20 percent by weight of A-1 alumina merely sintered and maintained its

\footnotetext{
${ }^{4}$ W. N. Harrison, R. E. Stephens, and S. M. Shelton, Consistency of eight types of vitreous enamel frits at and near firing temperatures, J. Research NBS 20, 39 (1938) RP1063.
} 
original sharp edges. The other oxide admixtures were not particularly effective in reducing the high-temperature flow of the frit. The larger size of the chromic oxide and iron oxide buttons in relation to the others is caused by a bubble structure and indicates a gas-forming reaction during the firing operation.

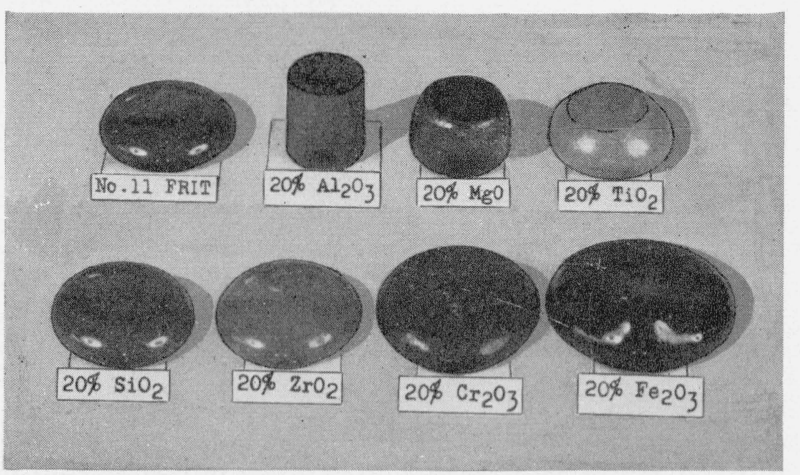

Figure 1.-Effect of 20-percent admixtures of various oxides on the fusion properties of a "hard" porcelain-enamel ground-coat frit when prepared as cylinders $5 / 8 \mathrm{in}$. in diamiter by $3 / 4 \mathrm{in}$. high and fired for 10 minutes at $1,600^{\circ} \mathrm{F}$.

Note sharp edges remaining on specimen containing alumina.

Early in the study of alumina admixtures it was discovered that the type of alumina grain had a controlling influence on the characteristics of the coating. For example, it was found that fused alumina, or alumina calcined at a high temperature, gave dense, glossy coatings when so fired as to give satisfactory adherence. These glossy coatings all showed reboil when heated to appropriate temperatures. Other grades of alumina, calcined at lower temperatures and available commercially at reasonable cost, gave mat coatings that were free of reboil when substituted in the same formula in like amount. $A-1$ alumina (table 2) obtained from the Aluminum Ore Co., East St. Louis, Ill., was of this type and was used as the refractory admixtures in the coatings selected.

All the mat coatings prepared with $A-1$ alumina were somewhat porous, and it is believed that this porosity is responsible for the absence of reboil blisters when coated specimens are heated through the range $1,050^{\circ}$ to $1,150^{\circ} \mathrm{F}$. The reboil gases are apparently able to pass through these porous coatings without blistering, whereas the imperviousness of the dense, glossy types is such as to entrap these gases, with the resultant formation of blisters.
TABLE 2.-Typical chemical and screen analyses of the A-1 calcined alumina used in the preparation of ceramic coatings

Typical chemical analysis 1

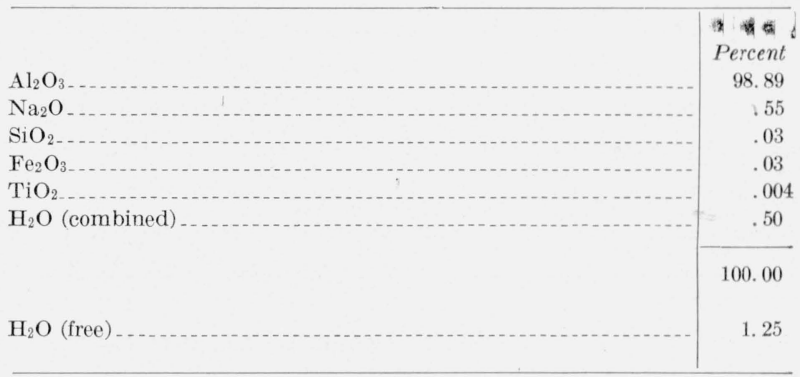

Typical screen analysis 1

Retained on No. 100 sieve

Through No. 100 on No. 200 sieve

Through No. 200 on No. 325 sieve.

Through No. 325 sieve..-

${ }^{1}$ Analysis by Aluminum Ore Co., East St. Louis, Ill.:

\section{Compositions of Coatings Selected}

Three of the coatings prepared with admixtures of $A-1$ alumina were found to be outstanding from the standpoint of appearance, ease of application, and adherence to the metal. ${ }^{5}$ The mill additions used in preparing these three coatings $(A-19$, $A-20$, and $A-55 \mathrm{~m}$ ) are given in table 3. A fourth coating, A-31, which also was found to possess certain desirable properties, consists of one cover

TABLE 3.-Mill batches used in the preparation of ceramic coatings $A-19, A-20$, and $A-55 m$

\begin{tabular}{|c|c|c|c|}
\hline \multirow{2}{*}{ Ingredient } & \multicolumn{3}{|c|}{ Parts by weight } \\
\hline & $A-19$ & $A-20$ & $A-55 \mathrm{~m}$ \\
\hline Frit $1^{1} \ldots$ & 50.0 & & \\
\hline Frit 11 & 50.0 & 100.0 & 100.0 \\
\hline Calcined alumina ${ }^{2}$ & 25.0 & 20.0 & 15.0 \\
\hline Enameler's clay ...... & 10.0 & 6.0 & 15.0 \\
\hline Black cobalt oxide... & ${ }^{3} 1.00$ & ${ }^{3} 0.25$ & ${ }^{3} 0.50$ \\
\hline Citric acid crystals ........ & 0.05 & .05 & .03 \\
\hline Water & 50.0 & 50.0 & 50.0 \\
\hline
\end{tabular}

1 The ratio of frit 1 to frit 11 may be varied in either direction when the resulting slip is better suited to local plant conditions.

${ }^{2}$ Aluminum Ore Co. $A-1$ (see table 2).

${ }_{3}$ This amount of cobalt oxide may be reduced or even eliminated without damage to performance characteristies. The nearly black color imparted by the cobalt is conducive to uniformity of appearance.

\footnotetext{
${ }^{5}$ Because of the unusual properties of the developed coatings, application was made for a Government patent. This application was originally filed under the provisions of Revised Statute 4814, which served to keep the subject matter in a confidential category. At the end of the war, the need for these restrictions no longer existed, and the patent application was released from this status in December 1945.
} 
coat of $A$-20 over a ground coat of $A-19$. Coatings of lower alumina content (10 percent and 5 percent) have been prepared and have less tendency to "burn-off" and have greater refractoriness than conventional porcelain enamels, but the coatings thus formed do not have a durability at high temperatures comparable to that of the $A-19, A-20$, or A-55m compositions.

Details regarding the milling, application and firing of the coatings are given in section $\mathrm{IV}-3$.

\section{Expansivity and Softening Temperatures}

Thermal-expansion and softening-point data were obtained with the Fizeau-Pulfrich interferometer $^{6}$ by the revised procedure of Saunders. ${ }^{7}$ The specimens for these tests were prepared in the following steps: 1. Pressing small disks of the partially dried slip; 2. Cutting out small pegs of the proper size and shape from the dried disk; 3 . Firing the pegs on a small 18-gage stainless-steel sheet for 5 minutes at $1,600^{\circ} \mathrm{F}$. Annealing was done by heating the specimens to $1,300^{\circ} \mathrm{F}$ and cooling them at a rate of $3^{\circ} \mathrm{F}$ per minute through the critical-temperature zone.

The following tabulation gives the coefficient of linear expansion per ${ }^{\circ} \mathrm{C}$ of frit 11 and of three coatings over the range $25^{\circ}$ to $400^{\circ} \mathrm{C}$ :

\begin{tabular}{l|r|r|r}
\hline \multicolumn{1}{c|}{ Material } & Expansivity & \multicolumn{2}{|c}{$\begin{array}{c}\text { Interferometer soften- } \\
\text { ing temperature }\end{array}$} \\
\hline & & ${ }^{\circ} \mathrm{C}$ & \multicolumn{1}{c}{${ }^{\circ} \mathrm{F}$} \\
Frit $11 \ldots$ & & 531 & 988 \\
Coating $A-55 \mathrm{~m}$ & 9.6 & 560 & 1040 \\
Coating $A-19$ & 10.2 & 589 & 1092 \\
Coating $A-20 \ldots .3$ & 592 & 1098 \\
& & & \\
\hline
\end{tabular}

Considering expansion coefficients only, these data would indicate that coatings $A-19$ and $A-20$ could be applied to low carbon steel, which has a coefficient of approximately $13.6 \times 10^{-6}$ over the same range, with less residual stresses on cooling than would be the case when a conventional ground coat prepared from frit 11 was applied. Experience has shown, however, that these new coatings cannot be applied in as heavy an application as conventional ground-coat enamels because of spontaneous chipping, a defect which ordinarily indicates an excessively high residual stress be-

${ }^{6}$ George E. Merritt, The interference method of measuring thermal expansion, BS J. Research 10, 59 (1933) RP515.

7 James B. Saunders, Improved interferometric procedure with application to expansion measurements, J. Research NBS 23, 179 (1939) RP1227. tween the coating and metal base. The temperature at which stresses are first introduced into the coating during cooling of the coated steel, which is related to the interferometer softening temperature, has an important influence on the residual stress. Coatings $A-19$ and $A-20$ become rigid at temperatures considerably above that for a normal ground coat, and therefore stresses are being introduced over a wider temperature range during cooling. Thus, although coatings $A-19$ and $A-20$ have higher thermal expansions than many conventional ground-coat enamels, they may, nevertheless, be under greater stress after cooling to room temperature.

\section{Laboratory Tests of Coatings}

During the same period that the development work was being carried forward on the ceramic coatings, laboratory tests were being devised that would rapidly give an indication of the relative suitability of the various commercial enamels that were being submitted for the protection of lowcarbon-steel exhaust systems. The A-19, A-20, and $A-31$ coatings were developed in time to be included in these tests. The $A-55 \mathrm{~m}$ coating, however, was a later development.

In two of the laboratory tests (flame impingement and air-blast thermal shock) the specimens coated with the conventional enamels were submitted by the respective manufacturers. For all other tests, the required enameled specimens were prepared and coated at the Bureau, using the ingredients supplied by the manufacturers. The manufacturers also supplied directions for the preparation, application, and firing.

The recommended firing temperatures for the conventional enamels varied from $1,550^{\circ}$ to $1,750^{\circ} \mathrm{F}$. The NBS coatings applied for the laboratory tests were fired at $1,600^{\circ} \mathrm{F}$.

One of the difficulties in devising suitable laboratory tests for the coatings was to provide conditions that would be representative of those under which aircraft exhaust systems operate. Little information as to the operating conditions was available at that time, but they were known to vary widely. For example, it was reliably reported that some short exhaust stacks, especially those that are only slightly curved, never become hot enough to give a red glow in the dark, even when used on powerful engines. The maximum 
temperature reached by such stacks is presumably below $1,000^{\circ} \mathrm{F}$. On the other hand, collector rings for turbo-supercharged engines were known to operate in some instances at temperatures sufficient to give a bright-red color at the hottest parts. The maximum temperature in this case was assumed to be well in excess of $1,250^{\circ} \mathrm{F}$. The temperatures suggested by the armed services for many of the tests reported herein $\left(1,100^{\circ} \mathrm{F}\right.$ and $1,200^{\circ} \mathrm{F}$ ) were chosen to represent intermediate conditions such as are encountered by stacks that are sharply curved near the inlets, and collector rings for some of the engines that are not turbo-supercharged.

Some reported measurements of the temperature of exhaust systems by means of thermocouples attached directly to the outer surface of the metal were so low as to be open to question because of the cooling effect of the surrounding atmosphere on the thermocouple hot junction. Errors can be minimized by spot-welding the respective wires of the thermocouples to the test specimen at slightly separated locations. This method was used in the present study to obtain temperatures of specimens not enclosed in a furnace.

It was observed that the shape of the test specimens had a strong effect upon the behavior of the coatings tested. Some of the test specimens were flat plates (4 in. by 6 in.) instead of being tubular, as in exhaust systems. The flat plates lacked the rigidity of tubes, and the specimens were often distorted by stresses resulting from severe thermal gradients. The effects produced must accordingly be considered as exaggerations of those which would occur in tubular specimens.

\section{Flame-Impingement Test}

The specimens used in this test were $4 \mathrm{in}$. by 6 in., and the enamel was applied to both sides of the 18-gage low-carbon steel in thicknesses of 0.003 in. to 0.004 in. A laboratory blast burner having an exhaust tube approximately $5 / 8$ in. in diameter and 3 in. in length was modified, as shown in figure 2 , by covering the mixing tube with an enameled cylinder 1 in. in diameter and 9 in. in length. This cylinder was adjusted at an angle of approximately 45 degrees to the horizontal plane in which the specimen was supported, the end being approximately $2 \frac{1}{2}$ in. from the specimen. A 22-gage platinum-to-platinum-10

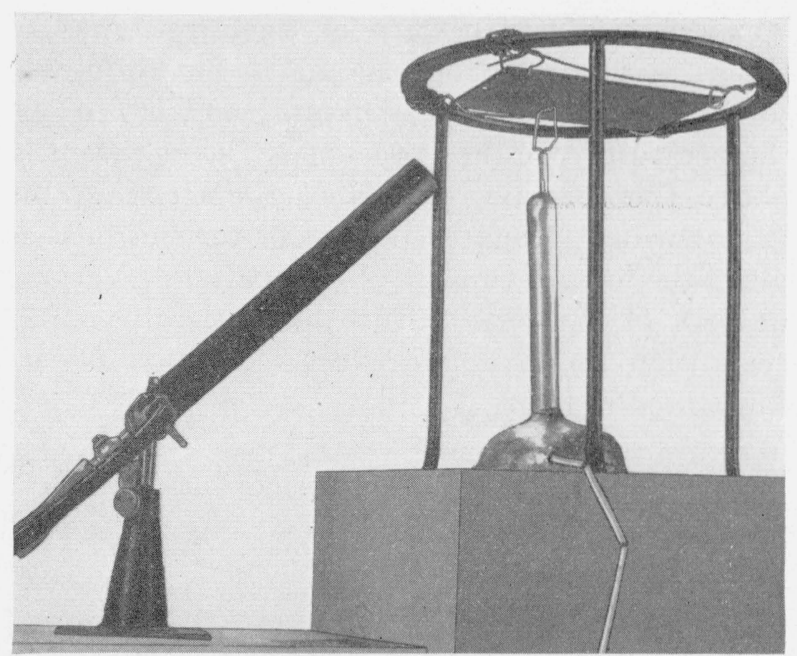

FIGURE 2.-Equipment used for flame-impingement tests with 4-by 6-in. specimen suspended from tripod.

The thermocouple beneath the specimen is used to control the flame temperature.

percent rhodium thermocouple was placed at the center of the flame $1 / 4 \mathrm{in}$. below the specimen. The air and gas were adjusted so that the thermocouple indicated a temperature of $1,700^{\circ} \pm 20^{\circ} \mathrm{F}$ with a specimen blank in position. When this condition was reached, the blank was removed and the flame was allowed to impinge on a test specimen for 15 minutes, after which the specimen was examined on both sides.

In a trial test the enamel over areas about $\frac{1 / 8}{8}$ in. in diameter and $1 / 4 \mathrm{in}$. apart was ground off the upper surface of the metal base of the specimen, opposite the central point of contact of the flame, and Chromel and Alumel wires were spotwelded at these areas. This thermocouple indicated the temperature of the metal to be $1,040^{\circ}$ $\pm 20^{\circ} \mathrm{F}$. During the actual tests, however, only the thermocouple shown in figure 2 was used to control the flame temperature.

Among the coatings thus tested, none showed evidence of failure from localized "crawling," in which the enamel separates, leaving streaks of apparently unprotected metal. The failures that did occur from this testing procedure were believed to be accentuated by a flexing, or buckling, of the metal, caused by stresses resulting from large thermal gradients accompanying the localized heating of a small area from the bottom surface. Fine cracks occurred on some specimens of the conventional enamels on the side where the enamel was placed in tension. These cracks 
apparently offered a path of least resistance to the gases escaping from the metal, but owing (1) to the constriction of the fissures and (2) to the temperature of the specimens being slightly above the softening points of the enamels, the gases formed elongated blisters or rows of blisters along the lines of rupture of the coating. Varying degrees of this effect from no noticeable effect (condition $A$ ) to severe effect (condition $D$ ) are illustrated in figure 3.
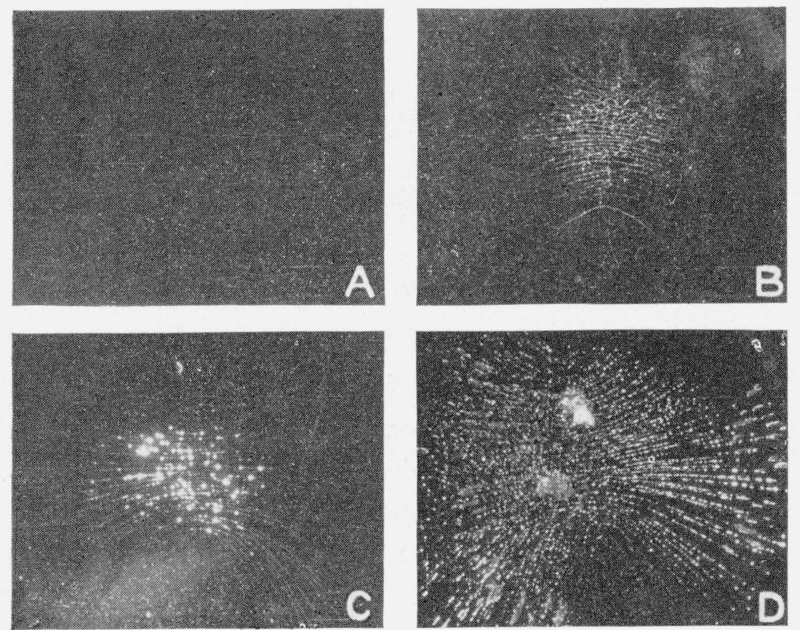

FIGURE 3.-Tension side of specimens typical of results obtained from both the flame-impingement and the air-blast thermal-shock test, illustrating varying degrees of damage to the coating.

Condition $A$ represents no effect.

The concave (compression) sides of specimens which were distorted by thermal gradients in the flame-impingment test sometimes showed a random distribution of blisters over the test area, illustrated in figure $4(I I)$. On other specimens there was a combination of cracks and blisters shown as condition $I I I$ in the same figure.
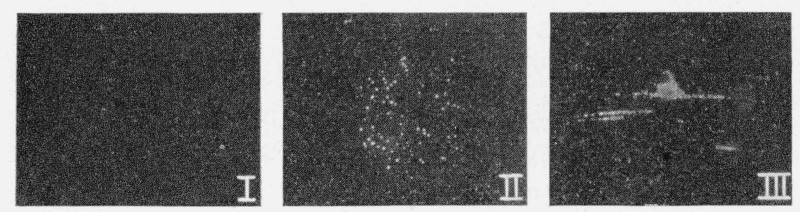

FIGURE 4.-Compression side of specimens typical of results obtained from both the flame-impingement and from the air-blast thermal-shock test, illustrating different types of damage to the coating.

Condition $I$ represents no effect.

The results of the flame-impingement test are given in table 4. Among the commercial enamels (indicated by $C$, followed by a numeral), $C-9$ and
$C-5$ had the best ratings, both sides of the specimens considered. NBS coatings $A-19$ and $A-31$ received the maximum rating for both the compression and the tension sides of the specimens.

TABLE 4.-Results of flame-impingement tests on 4-inch by 6 -inch coated specimens made with an indicated flame temperature of $1,700^{\circ} \mathrm{F}$ and specimen temperature of $1,040^{\circ} \mathrm{F}$

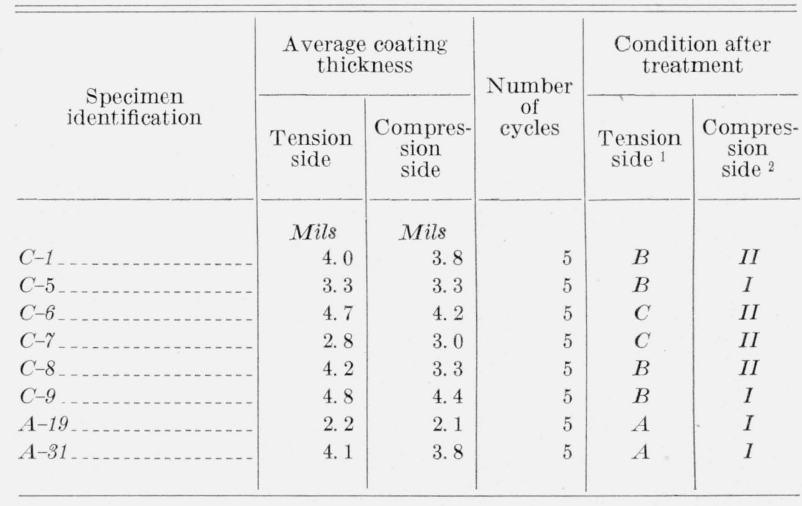

${ }^{1}$ Letter designations refer to condition of test area on tension side of flat specimen after treatment, as illustrated in figure 3.

${ }^{2}$ Numerals refer to condition of area on compression side of specimen after treatment, as illustrated in figure 4.

\section{Thermal-Shock Test by Air Blast}

The specimens for this test were the same as those used for the flame-impingement test (4-in. by 6 -in. plates).

Temperature measurements were made by means of Chromel and Alumel wires, separately spot-welded to each specimen after grinding off small areas of enamel at the middle of the test area. A Fisher burner, 1 1/8 in. outside diameter at the top, was placed approximately $1 / 2 \mathrm{in}$. below the specimen, which was supported as shown in figure 2, with the thermocouple on the upper side. The temperature of the specimen was allowed to increase rapidly until it reached $1,200^{\circ} \mathrm{F}$, at which time a blast of air at room temperature was released on the under side of the specimen. This blast immediately blew out the flame and reduced the temperature of the test area to $400^{\circ} \mathrm{F}$ within a period of 12 to 15 seconds. After five cycles of this treatment, the specimens were inspected and graded.

The results of the air-blast thermal-shock test are given in table 5. Among the commercial enamels, $C-9$ had the highest rating for this test. Experimental enamels $A-19$ and $A-31$ received the maximum rating for both the tension and the compression sides of the specimens, their condition 
after test being shown by $A$ in figure 3 and $I$ in figure 4 .

TABLE 5.-Rcsults of air-blast thermal-shock test $\left(1,200^{\circ}\right.$ to $400^{\circ} \mathrm{F}$ in 12 to 15 seconds) on 4 -inch by 6 -inch coated specimens

\begin{tabular}{|c|c|c|c|c|c|}
\hline \multirow{2}{*}{$\begin{array}{c}\text { Specimen } \\
\text { identification }\end{array}$} & \multicolumn{2}{|c|}{$\begin{array}{c}\text { A verage coating } \\
\text { thickness }\end{array}$} & \multirow{2}{*}{$\begin{array}{l}\text { Number } \\
\text { of cycles }\end{array}$} & \multicolumn{2}{|c|}{$\begin{array}{c}\text { Condition after } \\
\text { treatment }\end{array}$} \\
\hline & $\begin{array}{c}\text { Tension } \\
\text { side }\end{array}$ & $\begin{array}{l}\text { Compres- } \\
\text { sion side }\end{array}$ & & $\begin{array}{c}\text { Tension } \\
\text { side }^{1}\end{array}$ & $\begin{array}{l}\text { Compres- } \\
\text { sion side }{ }^{2}\end{array}$ \\
\hline & Mils & Mils & & & \\
\hline$C-1$ & 4.8 & 4.0 & 5 & C & $I I$ \\
\hline$C_{-5}$ & 3.4 & 3.5 & 5 & $C$ & $I I I$ \\
\hline$C-6$ & 4. 6 & 3.8 & 5 & $B$ & $I I I$ \\
\hline$C_{-\gamma} \gamma_{-}$ & 2.8 & 3.0 & 5 & $C$ & $11 I$ \\
\hline$C-8$ & 4. 3 & 3.6 & 5 & $D$ & $I I$ \\
\hline$C-9$ & 5. 6 & 4. 9 & 5 & $B$ & ${ }^{3} I I I$ \\
\hline$A-19$ & 2.0 & 2.2 & 5 & $A$ & $I$ \\
\hline$A-31=$ & 4. 2 & 3.7 & 5 & $A$ & $I$ \\
\hline
\end{tabular}

${ }^{1}$ Letter designations refer to condition of test area on tension side of specimen, as indicated in figure 3 .

${ }^{2}$ Numerals refer to condition of test area on compression side of specimen, as indicated in figure 4 ,

${ }^{3}$ Very slight.

\section{Thermal-Shock Test by Water Spray}

Tubular specimens 1 in. in diameter and $9 \mathrm{in}$. long, coated inside and out, were mounted as shown in figure 5. The specimens fit snugly into the top of the Fisher blast burner, with little or no leakage at this junction. A refractory tube, approximately 9 in. long, was placed at the top end of the specimen, a close fit being obtained also at this location. By adjusting the air and gas supplies, the flame could be regulated to burn within the enameled metal cylinder for a distance of several inches above the burner. For temperature measurement, Chromel and Alumel wires were spot-welded to the specimen after grinding off small areas of enamel approximately $5 / 8$ in. apart, at a level about $1 \frac{1}{2} \mathrm{in}$. above the top of the burner.

At the beginning of the test, the air and gas pressures were so adjusted as to cause the flame to burn within the tubular specimen, the hottest area being at the level of the thermocouple. When the thermocouple indicated $1,200^{\circ} \mathrm{F}$, a controlled spray of water was directed at the specimen while the flame still burned inside the tube. The water spray was continued until the specimen was cool enough on the outside for the water to form a film over the area between the points of attachment of the thermocouple wires. This operation required from 12 to 15 seconds for

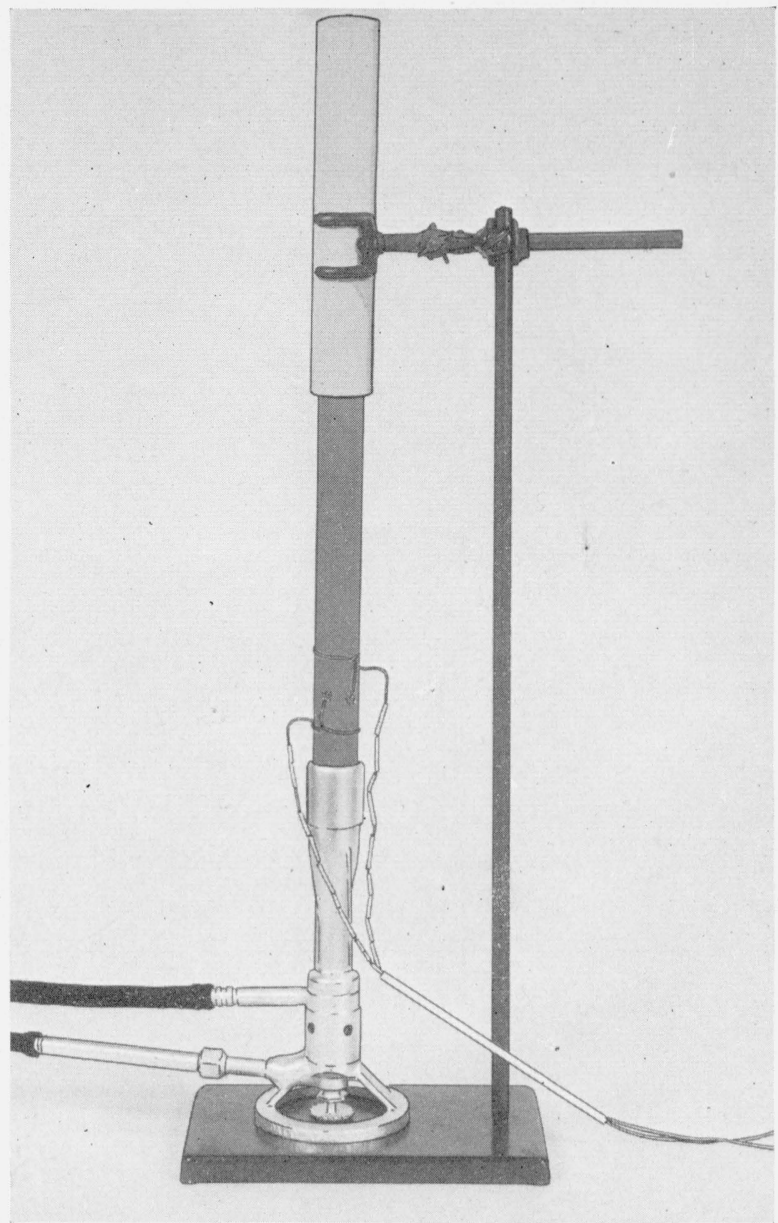

FIGURE 5.-Equipment for determining resistance of coatings to thermal shock by water spray.

Specimen is dark tube at center of assembly. Thermocouple wires are separately welded to specimen.

different specimens. Each specimen was given five cycles of this treatment.

Other tests were made in which the specimens were first quenched from $1,000^{\circ} \mathrm{F}$ for five cycles and then heated to $1,100^{\circ} \mathrm{F}$ and allowed to cool without quenching. Still other tests were made in which the specimens were given five quenches from $900^{\circ} \mathrm{F}$, after which they were heated to $1,100^{\circ} \mathrm{F}$ and allowed to cool without quenching.

The results of these tests are given in table 6 , in which the specimens are graded by letters. $A$ indicates no noticeable effect, as illustrated in figure $6, A ; B$ indicates the development of a pebbly surface resulting from blisters, as illustrated in figure $6, \mathrm{~B}$; and $C$ indicates chipping of the enamel, as illustrated in figure $6, C$. This chipping occurred in spots that had first blistered. 

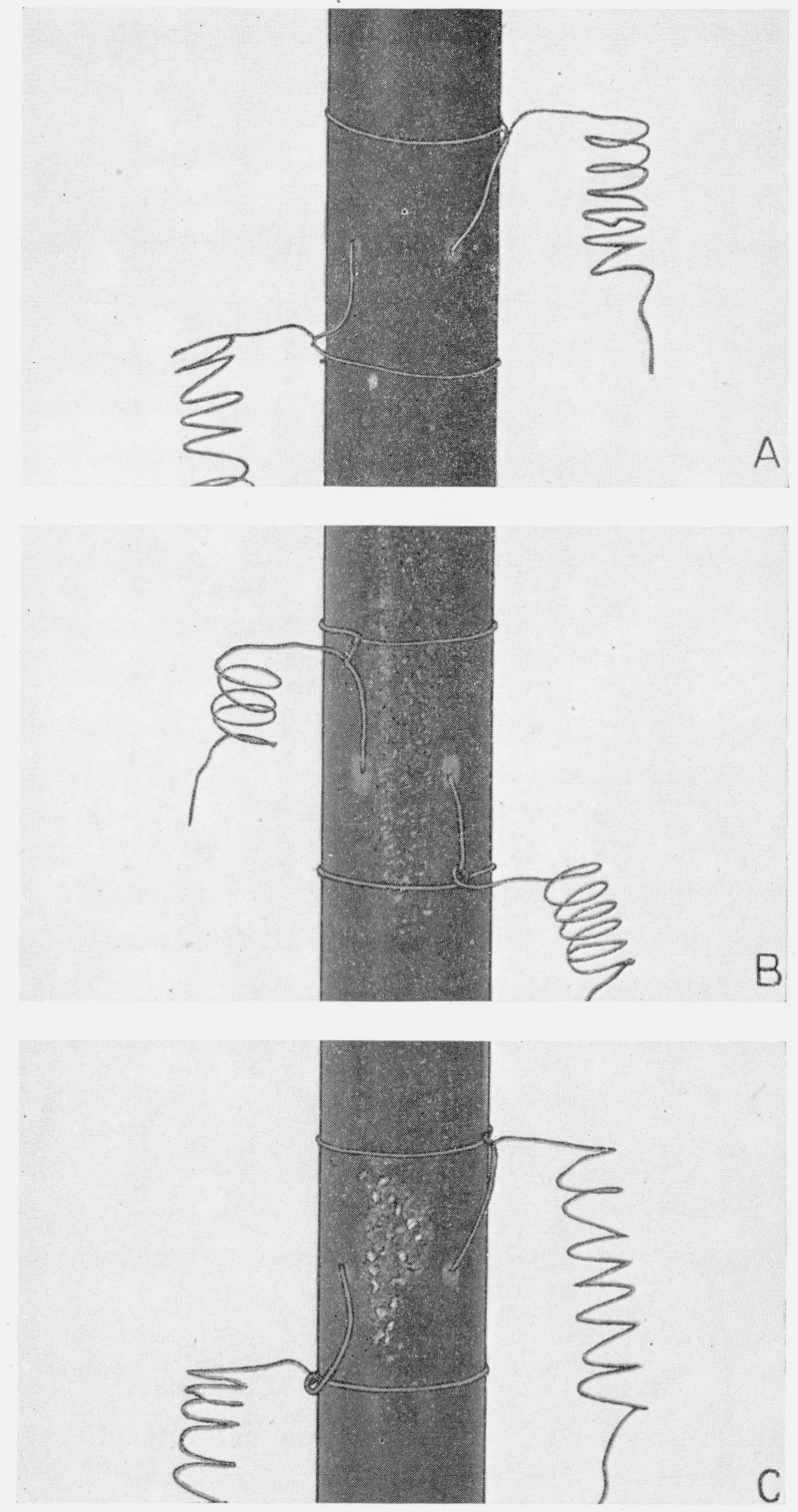

FIGURE 6.-Three degrees of damage resulting from the thermal-shock test by water spray.

Condition $A$ represents no noticeable effect; condition $B$, a pebbly surface resulting from blisters; and condition $C$, a chipping of the enamel in spots that had first blistered.

As shown in table 6 , none of the enamels was affected by five cycles of the water-spray quench from $900^{\circ} \mathrm{F}$ or $1,000^{\circ} \mathrm{F}$. On subsequent heating to $1,100^{\circ} \mathrm{F}$, however, damage occurred on all the conventional enamels. Quenching from $1,200^{\circ} \mathrm{F}$ also damaged all the commercial enamels. Enamel $C-9$ was outstanding among the conventional enamels in resisting the more severe temperature conditions. Coatings $A-19$ and $A-31$ rated grade $A$ throughout the water-spray quenching tests.
TABLE 6.-Results of thermal-shock tests with water spray on 1-inch-diameter ccated tubes

\begin{tabular}{|c|c|c|c|c|}
\hline \multirow{2}{*}{ Specimen identification } & \multirow{2}{*}{$\begin{array}{l}\text { Average } \\
\text { coating } \\
\text { thickness }\end{array}$} & \multicolumn{3}{|c|}{$\begin{array}{l}\text { Condition of test area after } \\
\text { five quenches from } 1\end{array}$} \\
\hline & & $900^{\circ} \mathrm{F}$ & $1,000^{\circ} \mathrm{F}$ & $1,200^{\circ} \mathrm{F}$ \\
\hline$C-1$ & $\begin{array}{l}\text { Mils } \\
\text { 4. } 0\end{array}$ & $2 A$ to $B$ & $2 A$ to $B$ & $C$ \\
\hline$C-5 \ldots$ & 3. 0 & $A$ to $B$ & $A$ to $C$ & $C$ \\
\hline$C-6 \ldots$ & 3.5 & $A$ to $B$ & $A$ to $C$ & $C$ \\
\hline$C-\gamma_{-\ldots}$ & 3.5 & $A$ to $B$ & $A$ to $C$ & $C$ \\
\hline$C-8 \ldots$ & 3. 6 & $A$ to $B$ & $A$ to $B$ & $C$ \\
\hline$C-9 \ldots$ & 3.4 & $A$ to $B$ & $A$ to $B$ & $B$ \\
\hline$A-19 \ldots$ & 2. 3 & $A, A$ & $A, A$ & $A$ \\
\hline$A-31 \ldots$ & 4. 2 & $A, A$ & $A, A$ & $A$ \\
\hline
\end{tabular}

1 Letter designations refer to the relative severity of effects, as illustrated in figure 6 . $A$ indicates no noticeable effect; $B$, blistering; and $C$, blistering followed by chipping.

2 The first letter in all cases indicates the condition of the test area after five quenches from the indicated temperature. The second letter gives the condition of this same area after subsequent heating to $1,100^{\circ} \mathrm{F}$ without further quenching.

\section{Thermal-Shock Test by Immersion in Water}

Flat 18-gage low-carbon-steel specimens 4 in by 6 in. were used for this test. They were initially heated in an oven, the temperature of which was held slightly above $600^{\circ} \mathrm{F}$. A thermocouple was kept in contact with the upper surface of the specimen, and when it indicated that the specimen had reached $600^{\circ} \mathrm{F}$, the specimen was removed rapidly from the oven and immediately imimersed to a depth of $3 \mathrm{in}$. (one half submerged) in water at $75^{\circ} \pm 5^{\circ} \mathrm{F}$. The specimen was then examined for damage and, if none had occurred, it was given a second cycle of treatment at an oven temperature of $700^{\circ} \mathrm{F}$. In each succeeding cycle the temperature was raised $100^{\circ} \mathrm{F}$, and these treatments were continued until failure occurred or until the specimen was quenched from $1,600^{\circ} \mathrm{F}$. The temperatures at which failure occurred, as indicated by spalling off of the coating, are given in table 7 .

This quenching treatment with the 4 in. by 6 in. plates is probably much more severe than any encountered in service, but the data in table 7 serve to emphasize certain differences among the respective coatings. The "bead" referred to in the third column of table 7 is a very narrow strip of enamel at the extreme edge of a specimen and thicker than over the principal area. With care, beads can be minimized, but they are difficult to eliminate. The powerful effect of thickness upon thermal-shock resistance is evident from the differ- 
TABLE 7.-Thermal-shock tests by immersion in water

\begin{tabular}{|c|c|c|c|c|}
\hline \multirow{2}{*}{ Specimen identification } & \multirow{2}{*}{$\begin{array}{l}\text { Average } \\
\text { coating } \\
\text { thickness }\end{array}$} & \multicolumn{3}{|c|}{ Temperature for failure 1} \\
\hline & & $\underset{\text { bead }{ }^{2}}{\text { Chip in }}$ & Crazing & Failure \\
\hline$C-1$. & $\begin{array}{l}\text { Mils } \\
\quad 3.8\end{array}$ & ${ }^{\circ} F_{750}$ & ${ }^{\circ} F$ & ${ }^{\circ} F$ \\
\hline$C-5 \ldots$ & 3.4 & 700 & 1,000 & 1,100 \\
\hline$C-7 \ldots$ & 3.0 & 750 & 1,000 & 1,100 \\
\hline$C-8 \ldots \ldots$ & 4.5 & 750 & ....... & 1,000 \\
\hline$C-9 \ldots$ & 4.2 & 700 & 1,000 & 1,100 \\
\hline$A-19$ & 2. 0 & 1,000 & & $1,600+$ \\
\hline$A-31$ & 4. 2 & & & ]. 200 \\
\hline
\end{tabular}

1 Temperature from which specimen was quenched to produce failure. A plus value indicates that no failure occurred when quenched from the temperature indicated.

2 The "bead" is a very narrow strip of coating at extreme edge of specimen, thicker than elsewhere.

ences in the temperatures at which chipping occurred in the beads and those at which failure of the specimens as a whole occurred. It is also notable that coating $A-19$, which did not fail (except at the bead) even when quenched from $1,600^{\circ} \mathrm{F}$, had the thinnest coating of all the specimens tested-thinner than a coating of glossy porcelain enamel can be successfully applied in production.

\section{Test for Protection of Metal Against Oxidation}

As a measure of the degree of protection against oxidation of the metal provided by the various coatings, specimens were heated for prolonged periods at constant temperatures. In these tests it was assumed that there was no appreciable volatilization of the coating ingredients throughout the heating and that the gain in weight that occurred was due to oxidation of the metal. The oxide was in most cases absorbed in the coating as it formed until a saturation level was reached, at which stage the adherence usually deteriorated and the coating flaked off the specimen.

The specimens for the gain-in-weight tests were flat, 18-gage, enameling-iron plates, $1 \frac{1}{2}$ in. by $2 \frac{1}{2}$ in., having a small hole near one edge, and from which they were suspended during the test. The coated specimens were heated in air in a furnace in which the temperature could be controlled to within \pm 15 deg. F. The tests were made at $1,400^{\circ} \mathrm{F}$ for $32 \mathrm{hr}, 1,200^{\circ} \mathrm{F}$ for $77 \mathrm{hr}$, and $1,000^{\circ} \mathrm{F}$ for $252 \mathrm{hr}$.

Specimens were removed for inspection at frequent intervals, and weighings to the nearest milligram were made in order to follow the gain in weight.

A summary of the results of these tests is given in table 8. From these data it is apparent that the rate of oxidation of the coated metal decreases greatly with a decrease in the temperature of test. Both the total amount of weight gain for the entire test period and the rate of gain during the final interval decreased for each coating as the temperature of test was decreased from $1,400^{\circ}$ to $1,200^{\circ}$ to $1,000^{\circ} \mathrm{F}$, even though the length of the test period was increased. Data on experimental coating $A$-20 were included in table 8 because tests on coating $A-31$ had not been completed at $1,200^{\circ}$ and $1,000^{\circ} \mathrm{F}$, and it is believed that because of similarity of composition and the relative results obtained at $1,400^{\circ} \mathrm{F}, A-31$ should perform at least as well as $A-20$ at the lower temperatures.

TABLE 8.-Protection provided by different coatings against oxidation of enameling iron at high temperatures as indicated by gain in weight of $1 \frac{1}{2}$-inch by $2 \frac{1}{2}$-inch specimens

\begin{tabular}{|c|c|c|c|c|c|c|c|c|c|c|c|c|c|}
\hline \multirow{3}{*}{$\begin{array}{l}\text { Specimen identifi- } \\
\text { cation }\end{array}$} & \multicolumn{4}{|c|}{ Test at $1,400^{\circ} \mathrm{F}$} & \multicolumn{4}{|c|}{ Test at $1,200^{\circ} \mathrm{F}$} & \multicolumn{5}{|c|}{ Test at $1,000^{\circ} \mathrm{F}$} \\
\hline & \multirow{2}{*}{$\begin{array}{c}\text { Coating } \\
\text { thick- } \\
\text { ness }\end{array}$} & \multicolumn{3}{|c|}{ Gain in weight } & \multirow{2}{*}{$\begin{array}{l}\text { Coating } \\
\text { thick- } \\
\text { ness }\end{array}$} & \multicolumn{3}{|c|}{ Gain in weight } & \multirow{2}{*}{$\begin{array}{l}\text { Coating } \\
\text { thich- } \\
\text { ness }\end{array}$} & \multicolumn{4}{|c|}{ Gain in weight- } \\
\hline & & At $\mathrm{hr}^{151 / 2}$ & At $32 \mathrm{hr}$ & $\begin{array}{l}\text { Rate } 15 \frac{1}{2} \\
\text { to } 32 \mathrm{hr}\end{array}$ & & At $15 \frac{1 / 2}{\text { hr } 1}$ & At $77 \mathrm{hr}$ & $\begin{array}{l}\text { Rate } 50 \\
\text { to } 77 \mathrm{hr}\end{array}$ & & At $15 \frac{1 / 2}{\mathrm{hr}}$ & At $78 \mathrm{hr}$ & At $252 \mathrm{hr}$ & $\begin{array}{l}\text { Rate } 78 \\
\text { to } 252 \mathrm{hr}\end{array}$ \\
\hline$C-1$ & $\begin{array}{l}\text { Mils } \\
\quad 3.4\end{array}$ & $\begin{array}{l}m g \\
\quad 120\end{array}$ & $\begin{array}{l}m g \\
\quad 156\end{array}$ & $\begin{array}{l}m g / h r \\
2.18\end{array}$ & $\begin{array}{l}\text { Mils } \\
\quad 3.0\end{array}$ & $m_{22}$ & $m_{41}$ & $\begin{array}{l}m g / h r \\
0.33\end{array}$ & $\begin{array}{l}\text { Mils } \\
\quad 3.5\end{array}$ & $m_{3}$ & $m_{8}$ & $m_{17}$ & $\begin{array}{l}m g / h r \\
0.052\end{array}$ \\
\hline$C-5 \ldots$ & 3. 6 & 129 & $(2)$ & $(2)$ & 3.8 & 15 & 69 & .81 & 3.4 & 1 & 2 & $\begin{array}{r}18 \\
5\end{array}$ & $\begin{array}{r}0.002 \\
.017\end{array}$ \\
\hline$C-6 \ldots$ & 3.9 & 146 & 223 & 4. 67 & 3.9 & 22 & 99 & 1. 22 & 4.4 & 3 & 7 & 14 & .040 \\
\hline$C-y_{\ldots} \ldots$ & 3.1 & 100 & 146 & 2.79 & 2.9 & 16 & 73 & .96 & 3.6 & 0 & 1 & 2 & .006 \\
\hline$C-8 \ldots$ & 3.3 & 147 & 212 & 3.94 & 3.5 & 11 & 69 & .85 & 3.3 & 1 & 4 & 9 & .026 \\
\hline$C-9 \ldots \ldots$ & 3.6 & 75 & 112 & 2.24 & 2.8 & 9 & 19 & .15 & 3.9 & 0 & 0 & 1 & .006 \\
\hline$A-13_{2} \ldots$ & 3.1 & 25 & 55 & 1.82 & 3.6 & 12 & 27 & .22 & 2.4 & 1 & 3 & 6 & .017 \\
\hline$A-20 \ldots \ldots$ & 2.4 & 42 & 69 & 1. 64 & 2.9 & 9 & 21 & .19 & 2.8 & 1 & 2 & 3 & .006 \\
\hline$A-\$ 1$ & 3.3 & 22 & 43 & 1. 27 & & & & & & & & & \\
\hline
\end{tabular}


At $1,400^{\circ} \mathrm{F}$, the newly developed coatings $A-19$, $A-20$, and $A-31$ gave lower gains in weight than any of the conventional enamels. Enamel $C-9$ was outstanding in its low gain in weight among the commercial group.

At $1,200^{\circ} \mathrm{F}$, coating $C-9$ gave the best results of all the coatings and $A-20$ was next. Both of the NBS coatings that were included ( $A-19$ and $A-20)$ permitted less total gain in weight and a lower rate of gain than any of the conventional coatings except $C-9$.

At $1,000^{\circ} \mathrm{F}$, the weight gain was low in all cases, but the relative position of coating $C-1$ changed, and in this test it had the largest weight gain, whereas $C-9$ had the least.

Coated specimens of both enameling iron and SAE 1020 steel were heated for various periods at $1,400^{\circ} \mathrm{F}$. Although these comparative data are not shown in table 8 , all coatings showed a tendency to chip off the 1020 steel spontaneously after prolonged treatment at $1,400^{\circ} \mathrm{F}$, whereas the same coatings on enameling iron, after comparable treatment, still showed fairly good adherence.

\section{Tests for Protection of Metal When Heated}

When studying adherence of coatings after the oxidation tests, it was noted that some specimens became brittle after prolonged periods of heating at temperatures above a red heat. It was noted also that the time of heating required to produce embrittlement as measured by a standardized impact depended on (a) the temperature, (b) the duration of treatment, (c) the type and amount of alloying, and (d) the protection against oxidation offered by the coating.

The embrittlement test as used in this work consisted in subjecting the specimen to impact at room temperature after various heating periods by allowing a 10-lb weight to fall from a height of 18 in. onto a 1-in.-diameter steel ball centered on the specimen so as to be directly over a $1 \frac{1}{8} /$-in.-diameter by $1 / 8$-in.-deep steel receptacle. Thus, the force of impact depressed the metal sheet over an area represented by the 1/8-in. diameter of the receptacle and to a depth of $1 / 8 \mathrm{in}$. at the center. Failure was indicated by any visible cracking of the metal in this test area.

Table 9 shows the difference in the time at elevated temperatures required to develop em- brittlement of the various metals studied. In all cases where comparisons were possible, the application of the $A-31$ coating materially increased the time at $1,400^{\circ} \mathrm{F}$ required for embrittlement failure. Other coatings acted similarly, their effectiveness being closely related to the degree of protection against oxidation. This observation suggests that the cause for the metal becoming brittle is closely associated with intergranular oxidation.

TABLE 9.-Results of the embrittlement tesis ${ }^{1}$ at room temperaiture for six metals, both uncoated and coated with A-31, after heating in air at the temperature indicated

\begin{tabular}{|c|c|c|c|}
\hline \multirow[b]{2}{*}{ Metal } & \multicolumn{3}{|c|}{ Time for embrittlement at- } \\
\hline & $\begin{array}{l}1,200^{\circ} \mathrm{F} \\
\text { uncoated }\end{array}$ & $\begin{array}{l}1,400^{\circ} \mathrm{F} \text {, } \\
\text { uncoated } 2\end{array}$ & $\begin{array}{l}1,400^{\circ} \mathrm{F}, \\
A-31 \text { coated }\end{array}$ \\
\hline & $h r$ & $h r$ & $h r$ \\
\hline Ingot iron $^{3} \ldots$ & $>64$ but $<112$ & $>5$ but $<11$ & $>200$ \\
\hline SAE 1010 & $>245$ & $>47$ & $>200$ \\
\hline SAE $1020 \ldots$ & $>245$ & $>31$ but $<47$ & $>200$ \\
\hline NAX 9112 & $>245$ & $>31$ but $<47$ & $>200$ \\
\hline SAE 4130 & $>245$ & $>47$ & $>200$ \\
\hline NE $8630 \ldots$ & $>245$ & $>31$ but $<47$ & $>200$ \\
\hline
\end{tabular}

Cracking of metal in a standardized impact test, as outlined in text, was taken as embrittlement failure.

${ }^{2}$ Longer heating times than $47 \mathrm{hr}$ not feasible because of oxidation of the metal.

3 Enameling iron.

TABLE 10.- Results of tensile-strength tests atroom temperature for six steels

\begin{tabular}{|c|c|c|c|c|c|c|}
\hline \multirow{3}{*}{ Steel } & \multicolumn{6}{|c|}{$\begin{array}{l}\text { Tensile strength at room temperature of 18-gage } \\
\text { tensile specimens heated- }\end{array}$} \\
\hline & \multicolumn{2}{|c|}{$\begin{array}{l}0 \text { hours at } \\
1,200^{\circ} \mathrm{F} \text {. }\end{array}$} & \multicolumn{2}{|c|}{$\begin{array}{c}250 \text { hours at } \\
1,200^{\circ} \mathrm{F}\end{array}$} & \multicolumn{2}{|c|}{$\begin{array}{c}500 \text { hours at } \\
1,200^{\circ} \mathrm{F}\end{array}$} \\
\hline & $\begin{array}{c}\text { A-31 } \\
\text { coated }\end{array}$ & Bare & $\begin{array}{c}A-31 \\
\text { coated }\end{array}$ & Bare 1 & $\begin{array}{c}A-91 \\
\text { coated }\end{array}$ & Bare 1 \\
\hline & $\begin{array}{l}\text { Kips/ } \\
\text { in. } .^{2}\end{array}$ & $\begin{array}{l}\text { Kips/ } \\
\text { in. } .^{2}\end{array}$ & $\begin{array}{c}\text { Kips/ } \\
\text { in. }{ }^{2}\end{array}$ & $\begin{array}{l}\text { Kips/ } \\
\text { in. } .^{2}\end{array}$ & $\begin{array}{c}\text { Kips/ } \\
\text { in. }^{2}\end{array}$ & $\begin{array}{l}\text { Kips/ } \\
\text { in } .^{2}\end{array}$ \\
\hline Ingot iron & 46.9 & 47.3 & 44.7 & 19.1 & 42.8 & 13. 1 \\
\hline SAE $1010 \ldots$ & 49.2 & 48.3 & 45.8 & 37.0 & 47.5 & 30. 7 \\
\hline SAE $1020^{2}$ & 70.8 & 71.4 & 54.3 & 48.8 & 50.4 & 40.4 \\
\hline NAX 9112 & 83.1 & 83.1 & 72.2 & 63.7 & 62.9 & 60.6 \\
\hline $\mathrm{SAE} 4130^{2}$ & 136.8 & 117.6 & 75.5 & 70.0 & 73.0 & 63.3 \\
\hline NE $8630^{2}$ & 123. 2 & 101.0 & 78.4 & 75.6 & 72.4 & 52.8 \\
\hline
\end{tabular}

1 Values in these columns are tensile strengths based on dimensions of the specimens after removal of scale.

${ }^{2} A-31$ coating was slightly blistered on these metals, and the resulting punctures in the coating reduced its effectiveness.

None of the data listed in table 9 is strictly quantitative. To overcome this objection, the American Society for Testing Materials tensile 
test, E8-42, was used in the hope of obtaining data that would be of value in determining more precisely the effect of the coatings. These data, which are given in table 10 , show that in all cases the specimens coated with $A-31$ retained more strength than uncoated specimens after having been heated for $250 \mathrm{hr}$ and $500 \mathrm{hr}$ at $1,200^{\circ} \mathrm{F}$.

\section{Directions for Commercial Application of Coatings}

\section{Suitable Types of Steels}

As is the case with conventional porcelain enamels, proper selection of steel is important also to the most satisfactory application of the hightemperature coatings. In general, single-coat applications can be made on any of the so-called low-carbon steels. In order to prevent blistering in two-coat applications of the $A-31$ type, however, the carbon content of the metal should preferably not exceed 0.15 percent.

Coatings of the $A-19$ and $A-20$ types can be satisfactorily applied on most high-temperature alloys of the austenitic types if the thickness of coating is kept below 0.003 in. The high thermal expansion of these alloys makes the heavier applications impracticable because of the tendency toward chipping due to excessive strains.

\section{Preparation of Metal}

The metal must be properly cleaned before application of the ceramic coatings if satisfactory results are to be obtained. In general, the metal must be more deeply etched than is common when ordinary porcelain enamel is applied. When feasible, sandblasting is recommended, but satisfactory adherence can be otained by pickling if a suitable procedure is used. Grease must be completely removed prior to pickling, and a heavy nickel flash is imperative even when the steel is cleaned by sandblast. For this purpose a 3 -percent solution of nickel-ammonium sulfate heated to $160^{\circ} \mathrm{F}$, and with the pH adjusted at $5.2 \pm 0.2$ with $\mathrm{H}_{2} \mathrm{SO}_{4}$, or $\mathrm{NH}_{4} \mathrm{OH}$, has been found effective. The recommended time of immersion of the cleaned metal in this solution is 15 minutes.

\section{Preparation, Application, and Firing}

The method of preparation of the new ceramic coating material is not appreciably different from the methods used for ordinary porcelain enamel ground coat. The frit and other mill batch materials listed in table 3 are introduced into the ball mill and ground to a fineness that will give the desired texture. This will usually require grinding until approximately 1 percent of the weight of the frit will be retained on a No. 200 sieve. $^{8}$

Before removing the slip ${ }^{9}$ from the mills, an additional $20 \mathrm{lb}$ of water per $100 \mathrm{lb}$ of frit is added, and the mills are then revolved for a few minutes to mix the added water. Final adjustment of the consistency of the slip is made by adding a solution of either citric acid or sodium pyrophosphate and by adding or drawing off water as needed. The recommended specific gravity is 1.60 to 1.62 for all three slips (table 3), although there is no objection to a somewhat higher or lower specific gravity if the dipping weight falls within the desired limits. The dipping weight for first coats is 0.42 to $0.49 \mathrm{oz}$ (12 to $14 \mathrm{~g}$ ) of dry enamel per square foot of surface. For second coats it is 0.28 to $0.35 \mathrm{oz}(8$ to $10 \mathrm{~g}$ ) per square foot.

Because of the fine grinding (ordinary groundcoat enamels are frequently ground to 6 to 8 percent retained a No. 200 sieve), longer milling periods are necessary. Experience has indicated that this milling time is increased approximately 50 percent over that needed for conventional ground coats.

The coatings may be applied to suitable shapes by spraying, but exhaust stacks and similar items having interior surfaces that require coating, must be dipped. The thickness of the fired coating for one-coat applications should be 0.002 in. to 0.003 in., the intermediate value of $0.0025 \mathrm{in}$. being sought. Thickness greater than 0.003 in. may be used, but heavier applications reduce thermalshock resistance and also are more likely to cause such defects as blistering or spontaneous chipping.

The firing temperature for the coatings on ordinary steels is $1,550^{\circ}$ to $1,600^{\circ} \mathrm{F}$. The time of firing varies with the gage of the steel, the size

\footnotetext{
8 Fineness of grinding influences the surface characteristics of the finish produced with the NBS ceramic coatings. When milled so that 2 or 3 percent of the frit is retained on a No. 200 sieve, a rough, full-mat surface results. With finer grinding ( 0.5 to 1.0 percent retained on a No. 200 sieve) the surface becomes smooth and satinlike. Extremely fine grinding of coating A-19, so that only a trace of material remains on a No. 325 sieve, produces a full gloss finish. A coating prepared in this way may be applied in very thin applications and has been designated as $A-19$.

${ }^{9}$ A sip is defined as the finely ground, creamy water suspension resulting from grinding the mill batch.
} 
and shape of the piece, and the furnace used. For small sample shapes made of 18-gage steel, the proper firing time is 4 to 5 minutes.

\section{Service Tests}

In the laboratory tests described in section III, wide variations were found in the resistance of the different coatings to the respective treatments. Whether these same coatings would perform similarly when applied to exhaust parts was not known and could be determined only by applying the various coatings to steel exhaust systems and making tests under the conditions of temperature and thermal gradients that exist during engine operation.

By early 1943, a number of exhaust parts had been coated and service tests were under way. By the time the testing program was terminated, a considerable number of sets of exhaust stacks, coated at the National Bureau of Standards, using both conventional enamels and the new ceramic coatings, had been tested by the Philadelphia Naval Air Experiment Station and the Norfolk Naval Air Station (both at the direction of the Navy Department Bureau of Aeronautics), the Army Air Technical Service Command at Wright Field, the Bell Aircraft Corp., and the Glenn L. Martin Co.

Collector-type exhaust systems also were coated. These were tested by the Army Ordnance Tank Automotive Center, the Navy Department Bureau of Aeronautics, the Aeronca Aircraft Corp., and the Grumman Aircraft Engineering Corp.

\section{Exhaust Stacks}

One of the first sets of exhaust stacks to be tested is illustrated in figure 7 . This shows the condition of the stacks after 178 hrs of block-test operation on a. 1,350-hp XR-1820-56 Wright radial motor. Coating $A-31$ shows no effect from the treatment, whereas the $C-9, C-1$, and $C-8$ coatings show the same type of defects noted earlier in the laboratory tests. The relative degree of damage follows the order that would be predicted from the flame-impingement and thermal-shock tests.

Two types of defects are present on the damaged stacks. One is a series of cracks following a design apparently corresponding to the strain lines caused by temperature gradients. The other defect consists of the formation of blisters of the type known in the enamel industry as "reboil." These eventually broke, leaving exposed metal beneath. Such blisters have a tendency to segregate along the cracks formed by thermal strains, whereas in other areas where no cracks are formed, they are scattered and show no definite pattern. These distributions correspond to those found in laboratory tests on flat specimens, as illustrated in figure 3.

Figure 8 shows two Glenn L. Martin No. 279305 stacks after 300 flying hours on a PBM-3D patrol bomber operating out of Norfolk, Va. The $A-31$ stack (on the left), which has an average coating thickness of 0.004 in., is not visibly affected by this treatment. The stack on the right, coated with $C-1$ in an average thickness of 0.0035 in., shows numerous broken blisters and cracks with serious rusting taking place at the discontinuities in the coating. The other service tests made on coated steel exhaust systems also, without exception, showed the newly developed coatings to be superior to the conventional glossy types. In no case did the $A-19$ or $A-31$ coating show either cracks or reboiling.

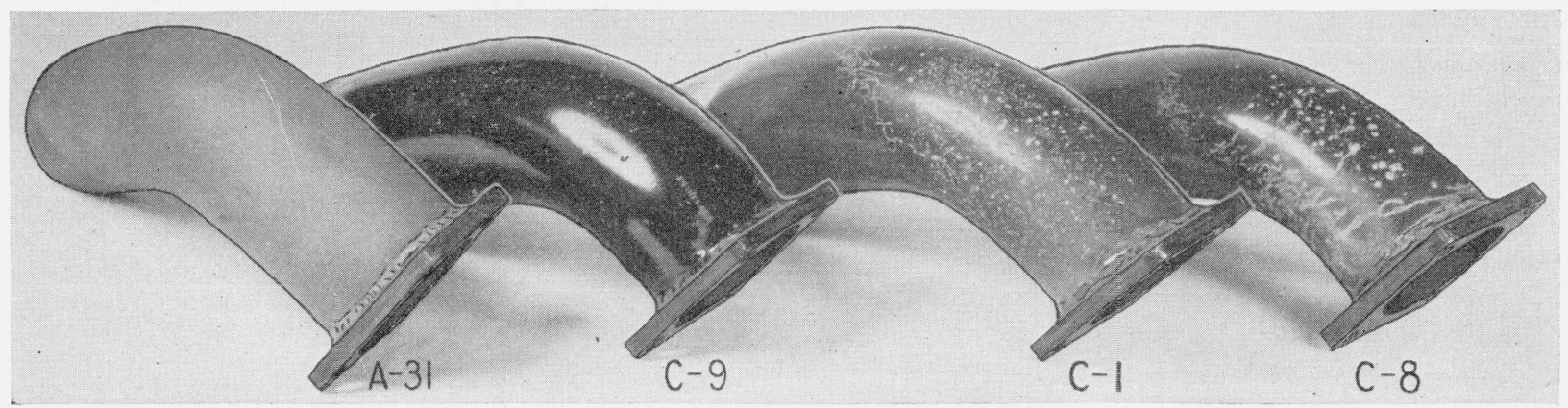

FIGURE 7.-Four coated sieel exhaust stacks after 178 hours of block-test operation on a 1,350-hp radial moior at the Naval Air Experiment Station, Philadelphia, Pa.

Coating $A-31$ is one of the heat-resisting compositions developed at the National Bureau of standards; $C-9$, $C-1$, and $C-8$ are three commercial coatings submitted for test. 


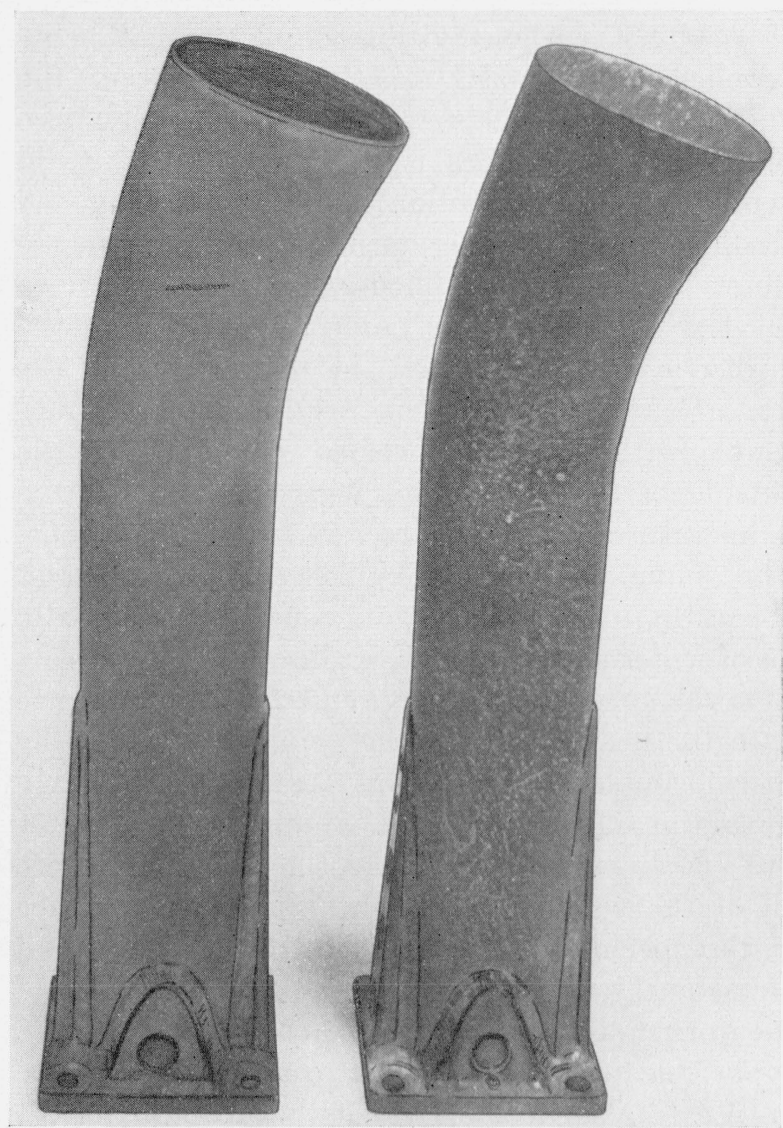

FIGURE 8.-Coated steel exhausi stacks lested simulianeously for 300 flying hours on a PBM-3D patrol bomber at Norfolk Naval Air Base.

Stack on left is protected with the NBS ceramic coating $A-31$ and is undamaged, whereas the stack on right, which is coated with commercial enamel $C-1$ shows scattered broken blisters, serious rusting taking place at the resulting breaks in the coating.

Some cracking of the metal was observed in service tests of stacks, especially those sharply curved near the inlets, and it was noted that steel having carbon contents in the range 0.10 to 0.25 percent were more resistant to such failure than was ingot iron. This observation was in agreement with the results of laboratory tests on embrittlement, given in table 9 .

NBS coatings $A-19$ and $A-31$ gave adequate protection to the steel, but because $A-19$ is a onecoat application, whereas $A-31$ requires two coats, the $A-19$ was recommended for exhaust-stack applications. Where metal temperatures near $1,250^{\circ} \mathrm{F}$ or somewhat above are encountered, $A-31$ is recommended in preference to $A-19$, but the strength properties of low-carbon steels are so low in this temperature range that the number of possible applications is limited. With special steels having better high-temperature strength, higher operating temperatures of coated stacks might be possible.

\section{Exhaust Collector Systems}

Tests made on collector parts for aircraft motors. gave results similar to those obtained on stacks. The $A-19$ and $A-31$ types again merited superior ratings when they were tested in direct comparison with the conventional glossy coatings.

Figure 9 shows sections from two of a series of coated collector rings tested under the supervision of the Tank Automotive Center of the Detroit Ordnance District of the Army Service Forces. These parts were tested on a 9-cylinder 450-hp Continental Motor of the type used on the M-4 tank. The part on the left was coated with $A-31$ and had been on the motor for $120 \mathrm{hr}$ of dynamometer operation. The other coating, which was one of the poorest tested, was a proprietary product of the glossy type applied by the manufacturer and had been under test for $13.5 \mathrm{hr}$, or only about one-tenth as long as the part coated with $A-31$. Except for a yellowish-brown deposit that accumulated during test, and which could be

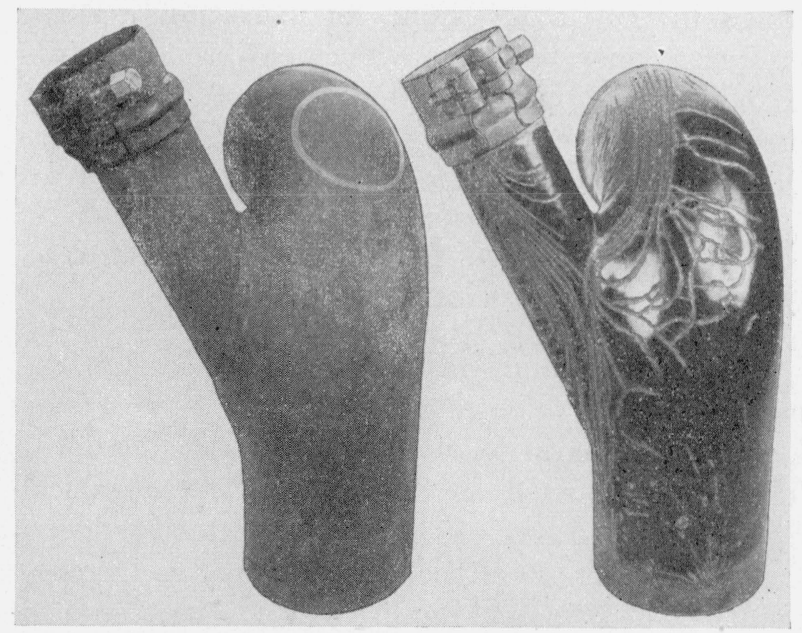

FIGURE 9.-Sections of coated steel collector rings after operation on a 450-hp, 9-cylinder Continental motor undergoing dynamometer tests.

The part on the right, which was protected with one of the poorest conventional enamel coatings, has undergone $13.5 \mathrm{hr}$ of test and shows pronounced chipping and cracking of the coating. The part on the left is protected with NBS ceramic coating $A-31$ and has undergone $120 \mathrm{hr}$ of testing without cracking or reboiling. The area within the circle was cleaned of grease and other external deposits, showing the undamaged coating beneath. 
readily removed by scouring ${ }^{10}$ there was no visible evidence of change in the $A-31$ coating. The glossy coating, on the other hand, shows serious cracking and chipping along certain strain lines with exposed metal appearing at the base of the damaged areas.

Proving-ground tests were made on 10 collector rings installed in tanks. One of these collector rings was coated with $A-19$ at the National Bureau of Standards, and the others were coated by seven enamel-frit manufacturers to whom the uncoated collector rings had been submitted by the Tank Automotive Center for application of coatings recommended by these manufacturers. After about 2,500 miles of operation on M-4 tanks only the $A-19$ coating received an excellent rating. The other coatings, without exception, showed damage, most of which consisted of thermal cracks and blisters.

Tests on other exhaust collector parts also showed the newly developed coatings to be superior. One finding in this part of the work was that the high-temperature strength of low-carbon steel is not sufficiently good to make the use of such steel feasible for the large collector rings on the more powerful motors, such as the 2,000-hp Wright radial motor. Two collector rings were coated for trial in this type of installation and failed in only a few hours of operation. These collectors operate above a red heat, and the lowcarbon steel apparently does not have sufficient strength to withstand this service, and the coating does not add materially to this strength.

\section{Specifications for High-Temperature Coatings}

The performance of the high-temperature ceramic coatings in both laboratory and service tests led to the preparation of appropriate specifications. These were issued as Army-Navy Aeronautical Specification AN-C-133 and as tentative specification AXS 1449 of the Army Ordnance Department. The principal requirements as written into these specifications are as follows:

(a) Thermal-Shock Resistance.-The coating must withstand five quenches from a temperature

\footnotetext{
10 Chemical analysis of the deposit revealed that lead was the principal constituent, comprising 72 percent of the inside and 44 percent of the outside deposit. The source of this lead must have been from the leaded fuel, leaky connectors being responsible for its presence on the outside surface of the collector ring. No carbon or iron was detected in either the inside or outside deposit.
}

of $1,200^{\circ} \mathrm{F}$ without visible damage, heat being supplied continuously to the underside of the quenched area. This test is performed on two coated, 18-gage tubes 6 in. long and $2 \frac{1}{2}$ in. in diameter, or on a section of exhaust tubing. A modified Meeker-type burner with a 90-degree elbow fitted onto the burner end is inserted into the test cylinder. The flame is lighted, and the burner is adjusted so that the temperature of the test area (as measured by a base-metal thermocouple with each wire welded separately to the outside of the steel tube) will pass through the temperature zone $1,185^{\circ}$ to $1,215^{\circ} \mathrm{F}$ in 30 seconds. The flame is then extinguished and relighted. When the temperature again reaches $1,200^{\circ} \mathrm{F}, 25$ $\mathrm{ml}$ of water at $70^{\circ} \pm 10^{\circ} \mathrm{F}$ is allowed to flow freely from the unconstricted large end of a $25-\mathrm{ml}$ pipette onto the heated area of the cylinder between the thermocouple welds. This treatment quickly cools the affected area to a temperature below $212^{\circ} \mathrm{F}$, as can be seen from the fact that before all of the water has left the pipette the surface of the specimen sustains a film of water instead of instantly vaporizing it as at the beginning of the quenching treatment. When the temperature again reaches $1,200^{\circ} \mathrm{F}$, the quench is repeated until a total of five cycles has been accumulated.

(b) Oxidation Resistance.-The protection of the metal against oxidation must be such that a $2 \frac{1}{2}-$ in . by 3 -in. coated specimen of 18-gage enameling iron shall not gain in weight more than $0.03 \mathrm{~g}$ during $48 \mathrm{hr}$ of heating at $1,200^{\circ} \mathrm{F}$.

(c) Thickness of Coating.-The thickness of coating must be not less than 0.002 in. nor greater than 0.003 in. on principal areas nor greater than 0.006 in. at beads.

\section{Production of Coated Exhaust Parts}

Commercial production of low-carbon-steel exhaust stacks with NBS ceramic coating $A-19$ was started in 1944. By the end of the war, three enameling companies had applied the coating to aircraft exhaust stacks in substantial quantities. As the shortage of stainless steel never became so acute as to restrict its use in aircraft, the $A-19$ coating on low-carbon steel was used through preference rather than through an enforced substitution.

Another application of the $A-19$ coating that reached the production stage before the end of the 
war was the coating of tail pipes for the exhaust systems of the amphibious truck, or "DUC". One section of this pipe was $9 \mathrm{ft}$ long by $1 \frac{3}{4}-\mathrm{in}$. in inside diameter, with S-shaped curves at each end. Two other sections were approximately $3 \mathrm{ft}$ and $2 \mathrm{ft}$ long, respectively, with $2 \frac{1}{2}$-in. inside diameters. It is considered significant that the coating could be applied satisfactorily to such complex shapes. These pipes were originally fabricated of uncoated low-carbon steel and failed rapidly in service, through corrosion. Not only high operating temperatures, but also proximity to, and contact with, ocean water contributed to the corrosion. Tests showed that coating $A-19$ provided satisfactory protection.

\section{Potential Uses of Coatings}

In addition to the use of the new coatings for the protection of low-carbon steel in various military exhaust systems, there are a number of other possible applications where the new coatings, or modifications thereof, might be beneficial in prolonging the life of steel parts that are subjected to relatively severe temperature conditions. A list of such potential applications would include the following: (1) Domestic stove parts, such as grates or burners, (2) industrial furnace parts, such as muffles, dampers, or burners, (3) parts for heat interchangers, (4) heat baffles for continuous enameling furnaces, (5) annealing boxes, and (6) mufflers and tail pipes for buses, trucks, and automobiles.

\section{Summary}

A new type of ceramic coating for the protection of mild steels in high-temperature service was developed during the war at the National Bureau of Standards, and was used by the Army and Navy on the exhaust systems of certain aircraft and other vehicles. Laboratory and service tests have shown these new coatings to be superior to conventional porcelain enamels for high-temperature service. The outstanding features of the coatings are (a) high resistance to chipping under repeated severe thermal shock, (b) protection of the metal against oxidation during prolonged exposure in air at temperatures up to about $1,250^{\circ} \mathrm{F}$, (c) freedom from the cracking and blistering produced in conventional porcelain enamels under comparable conditions of high temperatures and severe thermal gradients, and (d) a mat surface that does not show highlights and, therefore, decreases the visibility.

To prepare these coatings, a mixture of a special grade of calcined aluminum oxide and a conventional type of ground-coat frit is ground with water to appropriate fineness and is then applied to the metal, dried, and fired according to well-known methods. The coatings may be used on low-carbon steel in an unprecedently thin application of only 0.002 to 0.003 in.

Specifications were issued by the armed services, and the coating was used in regular production during the war on a number of exhaust parts by both the Army and Navy.

Modifications of these ceramic coatings are possible and may find a use for lower temperature applications.

The development of the new type of coating through the stages of laboratory study, service tests, and regular production was made possible by the cooperation of several agencies. The Navy Bureau of Aeronautics, Army Air Forces, and, Army Ordnance Department participated in the service testing of the new coatings in parallel with conventional types submitted by manufacturers. Several of the manufacturers and the Porcelain Enamel Institute were instrumental in promoting the use of porcelain enameled exhaust systems and participated in arrangements for some of the comparative tests, especially by the Tank Automotive Center. In addition, a number of aircraft companies cooperated by making extensive tests of the new NBS coatings in direct comparison with conventional porcelain enamels.

Washington, November 4, 1946. 